\title{
曲がり管と旋回流の組み合わせによるオリフィス背後の配管減肉に関する研究
}

\section{Study on Pipe-Wall Thinning behind an Orifice by the Combined Influence of Curved Pipe and Swirling Flow}

\author{
○菅野 翔（新潟大院） \\ 正 藤澤 延行（新潟大） \\ 正 山縣 貴幸 (新潟大) \\ 高野 剛(新潟大)
}

Sho KANNO, Graduate School of Science and Technology, Niigata University

Takayuki YAMAGATA, Visualization Research Center, Niigata University

Nobuyuki FUJISAWA, Visualization Research Center, Niigata University

Tsuyoshi TAKANO, Visualization Research Center, Niigata University

Key Words: Pipe wall thinning, Flow accelerated corrosion, Orifice flow, Swirling flow, PIV

\section{1. 緒 言}

原子力発電プラントの危機管理や安全運転には，プラ ントの各種配管における減肉の発生メカニズムの解明と それに基づく減肉の高精度予測技術が重要な研究課題で ある.配管減肉の発生原因の一つに流動加速腐食があり, これは配管材料の鉄イオンが内部の流動によって作動流 体中に溶解するために生じる物質輸送現象である。代表 的な例として, 2004 年に起きた美浜原子力発電所におけ る配管破損事故があり，オリフィス下流側配管に非軸対 称な減肉が発生したことで予想より大きな減肉が発生し たことが事故の原因と考えられている ${ }^{1)}$. 著者らはこの ような非軸対称な減肉現象のメカニズムを理解するため に，オリフィス背後の流動現象について可視化計測を行 い，わずかなオリフィスの偏心 $( \pm 0.8 \%)$ と旋回流の組 み合わせ効果により，オリフィス背後に偏流が発生し， 物質輸送現象が増強されることを示した ${ }^{2-4)}$. 一方，実機 配管系では，オリフィス上流側にエルボなどの曲がり部 が設置されている場合も多く，曲がり管と旋回流の組み 合わせ効果についても考察する必要がある。

本研究では，曲がり管と旋回流の組み合わせによって 形成される流れがオリフィスに流入した場合，オリフィ ス背後の流れ場に偏流が発生するかどうかについて実験 的に検討する。 また，曲がり管のない場合と比較するこ とで，曲がり管の影響について考察する.

\section{2. 実験装置および方法}

\section{1 実験装置}

実験装置は，ポンプ，整流部，測定部から構成される 回流水槽であり，作動流体は水である. Fig. 1 は整流部 および測定部の模式図である。整流部の背後に旋回流を 発生するためのスワーラを設置し，曲率半径が管内径の 1.5 倍であるロングエルボを含む助走区間を介して，計 測部のオリフィスが接続されている。ここで，管内径は $D=56 \mathrm{~mm}$ ，オリフィス絞り比は 0.6 (内径 $33.6 \mathrm{~mm}$ ) であり，スワーラ-エルボ間は $200 \mathrm{~mm}$ ，エルボーオリフィ ス間は $600 \mathrm{~mm}$ より助走区間は計 $800 \mathrm{~mm}$ である。スワ
ーラは，主流方向に対して一定角度傾けたステンレス製 の直線羽根を周方向に 6 枚固定した構造であり，計測部 での旋回流強度が同程度になるように，軸対称旋回流で は $30^{\circ}$, 非軸対称旋回流では 45॰のものを使用した。ただ し，軸対称旋回流の実験ではエルボを排除した直管によ り計測を行った。

\subsection{PIV 計測}

速度場計測に用いた PIV システムは, Nd: YAG パルス レーザ $(\lambda=523 \mathrm{~nm})$ ， モノクロ CCD カメラ $(1008 \times 1018$ pixels, 8 bits), パルスジェネレータで構成される. 流れ の可視化のためにレーザをシート光として照射し， トレ 一サとして直径約 $40 \mu \mathrm{m}$ のナイロン製粒子 (比重 1.02) を作動流体に加えた. PIV 計測は，Fig. 1 に示すように流 れの偏りを観測するため，管軸を含む垂直断面（ $x-y$ 断面） と二次流れを観察するための管軸に垂直な断面 $(x-z$ 断面 $)$ に対して行った。なお，本実験のレイノルズ数は Re（= $\left.U_{0} D / v\right)=1.9 \times 10^{4}$ とした. ただし， $U_{0}$ : 断面平均流速, $v$ : 動粘度である. 粒子の移動量は軸方向計測で 5 ピクセ ル，周方向計測で 2 ピクセル程度に設定したため, 速度 計測誤差は，それぞれ 2\%及び5\%程度である。

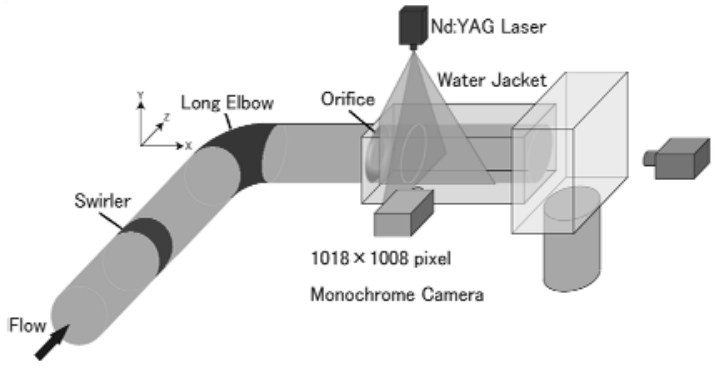

Fig. 1 Layout of test section.

\section{3. 実験結果および考察}

スワーラによって生成される旋回流強度は, 次式で定 義されるスワール数 $S w$ で表される.

$S w=\int_{0}^{R} u V_{t h} r^{2} d r /\left(R \int_{0}^{R} u^{2} r d r\right)$ 


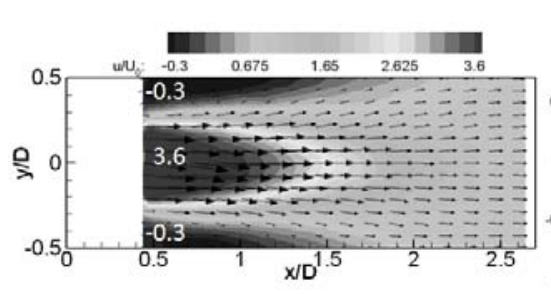

(a) Axial velocity

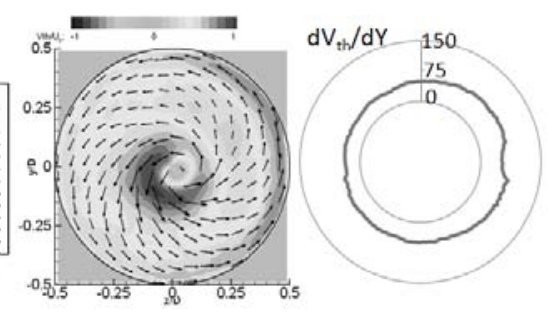

(b) $x / D=1.0$

Fig.2 Velocity distributions with swirling flow without curved pipe

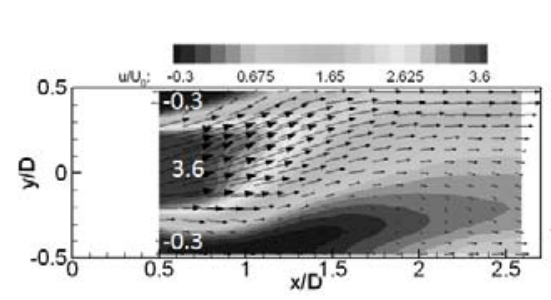

(a) Axial velocity

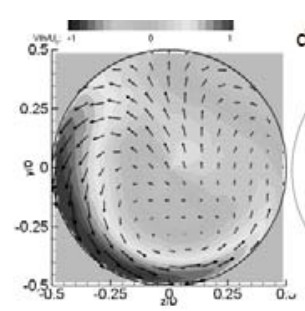

(c) $x / D=1.5$

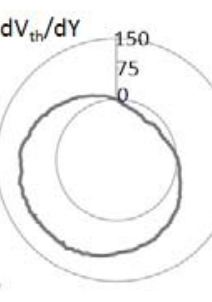

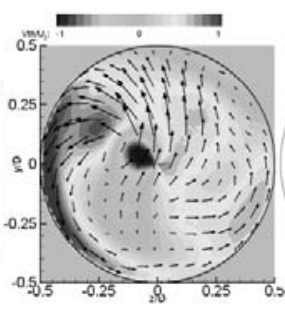

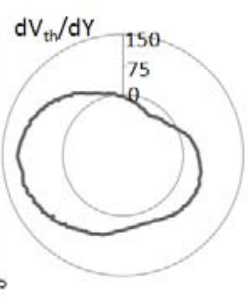

(b) $x / D=1.0$

(d) $x / D=2.0$

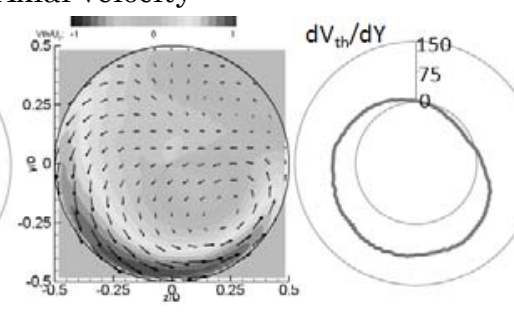

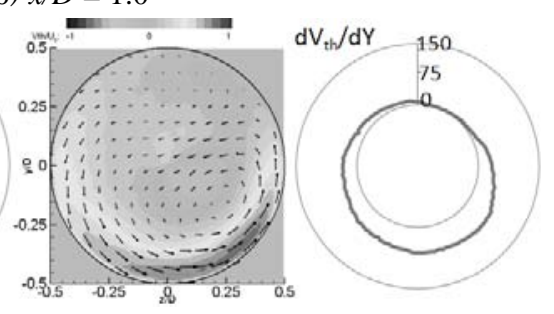

(e) $x / D=2.5$

Fig. 3 Velocity distributions with swirling flow and curved pipe

ただし, $R$ : 管半径, $r$ : 管中心からの距離, $u$ : 管軸方向 速度, $V_{t h}$ : 周方向速度である. オリフィスなしの本実験 のスワール数は，エルボを介した非軸対称旋回流では 0.30 , 直管での軸対称旋回流では 0.33 であり, 実機配管 の再現実験 1)と同程度に設定した。

Fig. 2 は, 曲がり管なし, 旋回流ありの条件下におけ るオリフィス背後の速度場の計測結果である.ただし, $x-y$ 断面の平均速度場(a) と $y-z$ 断面 $(x / D=1.0)$ における周 方向の平均速度場(b)を示寸. また, 配管減肉に直接関わ りを持つ物質輸送量として, 壁面からの無次元距離を $Y$, 周方向の無次元速度を $V_{t h}$ として, 管壁面における周方 向の無次元速度勾配 $d V_{t h} / d Y$ を評価した. ただし, これら の速度および速度勾配は, 断面平均速度 $U_{0}$ と管直径 $D$ で無次元化した。実験結果によると，オリフィス背後の 流れ場は中心軸に対して対称となっており, 上下壁面で の再付着点位置もほぼ一致している. また, 周方向速度 分布や速度勾配においても軸対称性が認められる。

Fig. 3 は, 曲がり管と旋回流が共にある場合のオリフ イス背後の速度場の計測結果である.ただし, $x-y$ 断面の 平均速度場(a), $y$-z 断面の周方向速度場として

$x / D=1.0(\mathrm{~b}), 1.5(\mathrm{c}), 2.0(\mathrm{~d}), 2.5(\mathrm{e})$ について示した. これら の実験結果によると, オリフィス背後の流れ場には, 非 軸対称の旋回流が発生し, オリフィス背後上方に向かう 強い偏流の発生が見られる. また, 周方向速度および速 度勾配の結果 $(x / D=1.0)$ によると, 左側の管壁に速度の大
きい領域が見られ, 壁面速度勾配も強い非軸対称性を示 す. さらに下流側の領域 $(x / D=1.5,2.0,2.5)$ では, 増速 は徐々に弱まり, それに伴って周方向速度勾配の大きさ も小さくなる．図より，下流に進むにつれて周方向速度 と速度勾配が共に大きい領域が，左側から下側に移動し ており, 速度勾配の大きさは徐々に減衰する。このこと は, 非軸対称旋回流が下流側で徐々に減衰することに対 応する. 一方, 本実験結果によると, 周方向速度の増速 領域は, オリフィスの下流側へ進むにつれて, 後方から 見て反時計周りに回転することが注目される.

\section{4. 結 言}

オリフィス背後における配管減肉現象の理解を目的と し，曲がり管と旋回流の複合した流れがオリフィスに流 入した場合の流れ場を実験的に検討した。 実験結果によ ると, このような複合流れを伴う流れ場では, オリフィ 又背後に強い偏流が発生し, 速度分布, 周方向速度勾配 に非軸対称性が顕著に見られることが分かった。

\section{参 考 文 献}

1) 経済産業省, http://www.meti.go.jp/committee/materials/g412 13aj.html, 資料 7-1-1, (2004)

2) Ohkubo, M. et al., J. Vis., Vol. 14 (2011), pp. 15-17.

3) 大久保雅一, 他 3 名, 日本機械学会論文集 B編, Vol. 77 (2011), pp. 386-394

4) 高野剛, 他 3 名, 保全学, Vol. 10 (2011), pp. 30-35. 